\title{
NVMO-congres 2001
}

In november 2001 vond voor de elfde keer het jaarlijkse congres van de Nederlandse Vereniging voor Medisch Onderwijs (NVMO), vroeger Gezond Onderwijs Congres (GOC) geheten, plaats in Veldhoven. Er waren in totaal 416 deelnemers en 99 voordrachten. Acht voordrachten vonden plaats op uitnodiging, de overige 91, het overgrote deel dus, op basis van initiatieven van de deelnemers om een abstract in te dienen.

In 2001 zijn voor het eerst de abstracts van feedback voorzien door twee reviewers en een lid van de organiserende werkgroep. Ook dienden de abstracts gestructureerd te worden volgens een vast stramien. Hiermee wordt gestreefd naar een hoge kwaliteit van de voordrachten. Ook werd in 2001 een nieuwe presentatievorm ingevoerd, de poster. In een postersessie werden de posters bekeken, kort gepresenteerd en werd vooral veel gediscussieerd. Het betreft een interactieve vorm die succesvol bleek en ruimte biedt om met elkaar van gedachten te wisselen over onderwerpen die nog niet geheel uitgewerkt zijn. Aan de beste poster werd een prijs toegekend. Tevens werd een posterborrelsessie georganiseerd, die druk bezocht werd en waarin het goed mogelijk bleek informeel contacten te leggen. Tot slot werd een wetenschappelijk comité opgericht ter ondersteuning van de Werkgroep NVMO-congres. De eerste informele bijeenkomst van dit wetenschappelijk comité vond plaats tijdens het congres in 2001 en vlak na het congres vond een evaluatiebijeenkomst plaats. Het comité adviseert de werkgroep over de inhoud en vorm van het congres en de wijze waarop het congres zich in de toekomst verder zou moeten ontwikkelen. Ook draagt het comité zorg voor een breed draagvlak in de achterban. Het comité bestaat uit Van der Vleuten (voorzitter), Ten Cate, Cohen-Schotanus, Denekens en Van Rossum. De Werkgroep NVMO-congres 2001 bestond uit Dolmans (hoofdorganisator), Fluit, De Jong, Remmen, Room en Sterman Vleeschdraager.

In het programma waren drie plenaire lezingen opgenomen, met als openingslezing de lezing van De Bie over competenties. Het betreft een modieus begrip dat echter consequenties heeft voor de inrichting van het onderwijs. Onderwijs zou studenten beter moeten voorbereiden op de competenties die vereist zijn in de latere beroepsuitoefening. De Bie gaf een aantal suggesties voor een andere aanpak van onderwijs. De tweede hoofdlezing werd verzorgd door Weggeman, die sprak over de zeer snelle veroudering van kennis. De vraag die centraal stond in zijn bijdrage, was hoe professionals ervoor kunnen zorgen dat ze tot op hoge leeftijd over kennis, die zich snel vernieuwd, kunnen blijven beschikken. Organisaties moeten ervoor zorgen dat ze efficiënt en innovatief zijn en daarvoor is een samenwerkingscultuur vereist. Het management moet de condities hiervoor realiseren. De derde hoofdlezing was de afsluitende lezing van Zwierstra en een aantal studenten. Zij blikten terug op het congres, tipten de parels aan in de voordrachten die gehouden zijn en noemden een aantal perspectieven die in de toekomst aandacht verdienen. Dit nummer van het 
Tijdschrift voor Medisch Onderwijs (TMO) bevat een beschrijving van de voordracht van De Bie en Zwierstra.

Verder waren in het programma vijf parallelle lezingen opgenomen. Sluijsmans besprak naar aanleiding van haar promotieonderzoek hoe peer assessment geïmplementeerd kan worden in opleidingen. Door middel van peer assessment worden studenten betrokken bij de beoordeling van elkaars competenties, een complexe vaardigheid, die zeer leerzaam is voor studenten. Bolhuis hield een lezing over professioneel leren. Levenslang leren is essentieel voor de professionele beroepsuitoefening. In de beroepsuitoefening wordt op velerlei manieren geleerd, formeel en informeel. Professioneel leren in de beroepspraktijk vereist dat lerenden kritisch leren reflecteren op hun eigen leren en handelen en dat van anderen. Stuyt deed in zijn lezing een aantal voorstellen voor maatregelen die een universitair medisch centrum kan nemen om gekwalificeerde medisch docenten te behouden en aan te trekken in de toekomst. Deze docenten zijn nodig om in de toekomst kwantitatief en kwalitatief voldoende artsen te kunnen opleiden. Splinter presenteerde het nieuwe curriculum geneeskunde aan de Erasmus Universiteit Rotterdam. De vijfde parallelle lezing werd verzorgd door het Studentbestuursleden Overleg Geneeskunde (SOG). Deze bijdrage bestond uit een interactieve forumdiscussie waarin gediscussieerd werd over de wijze waarop de ideale klinisch docent studenten begeleidt tijdens de co-assistentschappen. Penders, Van Dijk en De Doelder hebben voor dit nummer de meningen die geventileerd werden door het forum en de deelnemers op schrift gesteld. Ook van de andere vier parallelle lezingen wordt verslag gedaan in dit nummer.
Tijdens het congres zijn twee prijzen toegekend. De prijs voor de beste paper werd gewonnen door Schönrock-Adema en Van Oudenhoven-Van der Zee. Het betrof de rapportage van een goed opgezet onderzoek waarin werd nagegaan of de effectiviteit van een training in gespreksvaardigheden die grotendeels zonder begeleiding plaatsvond, verschilde van een zelfde training die voornamelijk onder begeleiding plaatsvond. Uit de resultaten bleek dat beide trainingsvormen effectief waren en dat zelfinstructie minstens even effectief was als begeleide training. De prijs voor de beste poster werd toegekend aan Van Beukelen et al. In deze poster werd geschetst hoe het nieuwe curriculum diergeneeskunde in Utrecht er vanaf 2001 uitziet. Een van de doelstellingen van het nieuwe curriculum is de invoering van gescheiden studiepaden. De opleiding diergeneeskunde en de opleiding humane geneeskunde kunnen wederzijds leren van ontwikkelingen die in het onderwijs plaatsvinden. Ook van de prijswinnaars zijn bijdragen opgenomen in dit nummer.

De overige voordrachten, posterpresentaties, ronde-tafeldiscussies en workshops tijdens het congres, 91 in totaal, zullen ongetwijfeld ook inspiratie en waarschijnlijk enkele artikelen opleveren, die niet in dit nummer van TMO, maar in een van de volgende nummers zullen verschijnen. De Werkgroep NVMO-congres 2001 hoopt dan ook dat de feedback op de abstracts ervaren is als een aanmoediging om hetgeen gepresenteerd is op het congres ook via dit tijdschrift verder te verspreiden. Het congres en het TMO zijn twee activiteiten van de NVMO die vooral bedoeld zijn als een platform om ervaringen en ideeën met elkaar uit te wisselen en op deze wijze van elkaar te leren.

Dit nummer geeft een indruk van de inhoud van het NVMO-congres in 2001. De 
bijdragen in dit nummer zijn beoordeeld en van feedback voorzien door de redactie van het TMO en de leden van de Werkgroep NVMO-congres 2001. Gezamenlijk hebben zij zorg gedragen voor de redactie van dit nummer. Congresdeelnemers kunnen in dit nummer interessante voordrachten nog eens nalezen of gemiste voordrachten alsnog inzien. Hopelijk kunnen we in 2002 weer rekenen op veel deelnemers, reeds bekende, maar ook nieuwe deelnemers, die na het lezen van dit nummer geïnteresseerd zijn in het congres.

In 2002 vindt het NVMO-congres plaats op 14 en 15 november 2002 op een nieuwe locatie: Egmond aan Zee. De organiserende werkgroep hoopt wederom een groot aantal abstracts te ontvangen. Voor meer informatie over het congres: e-mail: congres@nvmo.nl of de website van de NVMO: http://www.nvmo.nl.
De Gastredactie van dit nummer van TMO Werkgroep NVMO-congres 2001:

Dr. Diana H.J.M. Dolmans, hoofdorganisator, Universiteit Maastricht

Drs. Lia C.R.M. Fluit, Universitair Medisch Centrum St. Radboud Nijmegen Dr. ir. Peter G.M. de Jong, Leids Universitair Medisch Centrum

Dr. Roy Remmen, Universiteit Antwerpen Dr. Peter Room, Rijksuniversiteit Groningen

Mw. Marijke Sterman-Vleeschdraager, NVMO

Names de Gastredactie

Diana Dolmans, hoofdorganisator 